\title{
Special issue introduction
}

\section{Social psychological perspectives on the legitimation of social inequality: Past, present and future}

\author{
RUI COSTA-LOPES ${ }^{1 *}$, JOHN F. DOVIDIO ${ }^{2}$, CÍCERO ROBERTO PEREIRA ${ }^{1}$ AND JOHN T. JOST ${ }^{3}$ \\ ${ }^{1}$ Institute of Social Sciences - University of Lisbon, Lisbon, Portugal; ${ }^{2}$ Yale University, New Haven CT, USA; \\ ${ }^{3}$ New York University, New York, NY, USA
}

\begin{abstract}
This introductory article for the special issue entitled "Social Psychological Perspectives on the Legitimation of Social Inequality" reviews various theoretical frameworks applied to the study of this topic. Legitimation of social inequality occurs through individual-level, group-level, and system-level processes. In societies in which egalitarianism and fairness are core cultural values, legitimation permits differential treatment of people on the basis of their social group memberships while allowing people to maintain positive self-images, to reinforce group-based hierarchies and to justify a status quo that systematically benefits some individuals and groups more than others. In this article, we focus on three major theoretical perspectives in social psychology that have inspired most of the research featured in this special issue, and we offer a general overview of the articles to follow, expanding upon their connections to one another and to the theme of the issue. We highlight the promise of research on legitimation of social inequality not only for developing a deeper and more integrative theoretical understanding of intergroup relations but also for guiding interventions to achieve social equality in practice. Copyright () 2013 John Wiley \& Sons, Ltd.
\end{abstract}

\section{SOCIAL PSYCHOLOGICAL PERSPECTIVES ON THE LEGITIMATION OF SOCIAL INEQUALITY: PAST, PRESENT, AND FUTURE}

Fairness and justice are said to be fundamental human needs (Lerner, 1980; Lerner \& Clayton, 2011) that are rooted in evolved dispositions to experience inequity aversion (e.g., Boehm, 2012; Brosnan, 2006). Justice is part of the fabric of human society and is critical to the establishment of cooperation, reciprocity, and coordination that is necessary for group living (Tyler, 2011; see also Jost \& Kay, 2010). The fulfillment of justice standards brings with it a sense of control, predictability, satisfaction, and trust in the complexity of social interaction, and this, in turn, enhances mental and physical well-being (e.g., Luo \& Hsieh, 1997; O’Brien \& Major, 2005; Taylor \& Brown, 1988).

Yet, in a great many ways, life is plainly not fair. Group-based hierarchies within societies are ubiquitous and, according to some authors, are rooted firmly in human evolution (Sidanius \& Pratto, 1999; Somit \& Peterson, 1996). Historical and cross-cultural analyses reveal that members of dominant groups enjoy more privileges, have greater access to social and material resources, and are given more opportunities for social advancement than members of non-dominant groups (e.g., Blumer, 1958; Corning, 2011; Sidanius \& Pratto, 1999). Such privileges may be earned, but often they are not. By virtue of the lottery of birth and social category memberships alone, members of dominant groups and classes often receive far-better opportunities for success and well-being than do members of subordinate groups-irrespective of considerations such as individual merit or deservingness.

Hierarchical relations between social groups are by no means unchangeable, but they are surprisingly stable across time. Social psychologists have argued that inequality persists not only because of the coordinated efforts of members of dominant groups but also, to some extent, because of active and passive forms of support provided by members of nondominant groups (e.g., Jost, Banaji, \& Nosek, 2004). The stability of inequality is remarkable-and some would say worrisome-given the dramatic disparities of wealth, opportunity, and privilege that exist in the society. In contemporary capitalist societies, such disparities appear to be growing wider over time. In an ironic twist, the motivation to perceive existing arrangements as fair and just may contribute to the acceptance and legitimation of social inequality, insofar as it leads people to blame individual victims for their plight rather than situational or societal factors (e.g., Hafer \& Bègue, 2005; Jost \& Kay, 2010; Lerner, 1980).

This special issue of the European Journal of Social Psychology presents new research illuminating several important facets of the legitimation of social inequality. These contributions illustrate the value of investigating the phenomenon at multiple levels of analysis. The articles in this special issue adopt distinct but largely complementary theoretical perspectives. Taken as a whole, they cover social structural influences (e.g., perceived longevity and stability of the social system), 
intergroup processes (e.g., social identification and threat perception), individual differences (in prejudice, personality, and ideology), and developmental changes (in children). The work ranges impressively in terms of theoretical and methodological approaches, geographical reach, dimensions of social and economic inequalities, and the sheer variety of antecedents and outcomes associated with the process of legitimation.

In this introductory essay, we offer a brief theoretical overview of work on the social psychological legitimation of inequality. We outline scholarly progress in historical terms, introduce the most influential contemporary perspectives, and highlight the novel contributions of the articles in this special issue. Specifically, in the next section, we review some of the most basic concepts and approaches related to the legitimation of inequality. After that, we focus on three major theoretical perspectives in social psychology that have inspired most of the research featured in this special issue. Next, we offer a general overview of the articles to follow, expanding upon their connections to one another and to the theme of the issue.

\section{THE CONCEPT OF LEGITIMATION IN SOCIAL SCIENCE}

The concept of legitimacy has been central to Western philosophical thought since at least the time of ancient Greece (e.g., Tyler, 2006; Zelditch, 2001). Legitimacy generally refers to the perception that a given actor (or action) is consistent with socially accepted principles, standards, and expectations (e.g., Berger \& Luckmann, 1966; Johnson, Dowd, \& Ridgeway, 2006; Luhmann, 1969). Or, as Zelditch (2001) explained, "something is legitimate if it is in accord with the norms, values, beliefs, practices, and procedures [that are] accepted by a group" (p. 33).

Within social psychology, legitimacy reflects "the belief among members of a society that there are adequate reasons" for a request or behavior (Tyler, 1997, p. 323) — that it is “appropriate, proper, and just" (Tyler, 2006, p. 375). Legitimacy allows individuals and groups to exert influence over others to gain voluntary deference in the absence of coercion. Although much research on legitimacy has focused on compliance with authority figures and their demands (see Tyler, 2006) for a review), perceptions of legitimacy are also central to judgments and attributions about whether actions, events, and social systems are fair and just (Jost \& Major, 2001; Lerner, 1980).

Legitimation refers to the social and psychological processes by which attitudes, behaviors, and social arrangements are justified as conforming to normative standards-including, but not limited to-standards of justice. In societies in which equality is enshrined as one of the pillars of social organization, legitimacy and legitimation constitute key elements of stable relations within and between social groups. Individuals are more willing to comply with authorities, even when it entails personal sacrifice, to the extent that they perceive those authorities as having been selected through legitimate means and their decision-making procedures as fair (Tyler \& Blader, 2000).

Legitimacy is also a critical factor in intergroup relations. According to social identity theory, individuals derive self- esteem from their memberships in social groups and are therefore motivated to promote the positive distinctiveness of the groups to which they belong (Tajfel \& Turner, 1979). The manner in which individuals satisfy their needs for self-esteem through their affiliations with social groups is determined by (among other things) their beliefs about status relations between groups, the perceived legitimacy of those relations, and the permeability of intergroup boundaries. For example, perceiving status relations as illegitimate and unstable, and group boundaries as impermeable, is theorized to stimulate collective action on the part of low-status group members (van Zomeren, Postmes, $\&$ Spears, 2008). By contrast, viewing status differences as stable and legitimate, and group boundaries as permeable, leads members of low-status groups to disidentify with their own group and to seek membership in a higher-status group (Ellemers, 2001). It follows that ideological processes of system legitimation - that is, claims about whether inequality between groups is or is not justified - crucially affect relations among individuals and groups in society (Jost \& Major, 2001; Moscovici, 1988, pp. 221-222).

The emphasis of much recent work-which is the topic of this special issue-is on how social and psychological processes of legitimation can contribute to the stability of putatively unfair relations within and between groups. Decades of research on prejudice (and intergroup biases more broadly) implicate legitimation as a key mechanism underlying the perpetuation of inequality (Dovidio, Hewstone, Glick, \& Esses, 2010; Jackman, 1994; Jost \& Banaji, 1994; Major, 1994; Tajfel, 1981). Legitimation has been identified as a critical factor supporting sexism (Jackman, 1994), racism (Sidanius \& Pratto, 1999), and classism (Hochschild, 1981; Kluegel \& Smith, 1986). It played a major ideological role in the creation and maintenance of slavery (Faust, 1981; Fields, 1990), and it continues to play a major role in shaping anti-immigration legislation and "official language" policies. At the same time, perceptions of legitimacy are essential to processes of persuasion and social influence, cooperation with authorities, political movements, and so on (e.g., Kelman, 2001; Raven \& French, 1958; Tyler, 2006). For this reason, Jost and Major (2001) highlighted the "double-edged" nature of legitimation processes:

Although processes of legitimization and delegitimization can serve disastrous ends, such as the preservation of unjust, oppressive systems of social stratification, they can also serve the causes of justice, progress, and social change (p. 12).

Empirical research on the legitimation of inequality as a "dependent variable" - that is, an outcome of focal interestdid not receive concentrated attention in social psychology until the mid-1990s (Jost \& Major, 2001; Tyler, 1997). This is somewhat surprising, given that legitimation processes were assumed in several research lines of social psychological research, such as Milgram's (1974) experiments on obedience to authority and Lerner's (1980) demonstrations of victim blaming in response to threats to the belief in a just world as well as other studies of justice behavior and social exclusion (e.g., Darley, 1992; Deutsch, 1985; Opotow, 1990; Tyler, 1989). Sustained, systematic attention to the social, cognitive, and motivational dynamics of legitimation followed the development of theoretical frameworks associated with aversive racism (Dovidio \& Gaertner, 2004; 
Gaertner \& Dovidio, 1986), social dominance (Sidanius, 1993), and system justification (Jost \& Banaji, 1994). We briefly summarize the guiding assumptions of each framework before turning to a consideration of the articles included in this special issue.

\section{CONTEMPORARY PERSPECTIVES ON THE LEGITIMATION OF INEQUALITY}

Contemporary approaches to legitimation focus on different levels of analyses and the different functions that legitimation serves at the individual, group, and societal levels. At the individual level, legitimation can allow people to maintain positive self-images, personally as well as publicly, while still discriminating against others in subtle ways. At the group level, legitimation reinforces the advantaged position of dominant groups while reducing resistance-and sometimes promoting the acceptance- of non-dominant groups for occupying a disadvantaged position in the group hierarchy. At the societal level, psychological tendencies to defend, bolster, and justify aspects of the status quo shape the worldviews of those who are most invested in the social system. These different influences are complementary, operating in concert to affect attitudes, beliefs, aspirations, and behaviors in ways that contribute to the stratification of social life. In the next sections, we review various individual-level, group-level, and system-level perspectives that have been influential when it comes to the study of legitimation and are especially relevant to the articles in this special issue.

\section{Aversive Racism and Maintenance of Self-Image}

Equality is a core value in most societies (Schwartz, 1992), and it typically ranks high in individuals' hierarchies of personal values (Rokeach, 1973). Overtly racist, sexist, and classist beliefs and attitudes are far less common now than they were half a century ago (e.g. Schuman, Steeh, Bobo, \& Krysan, 1997). Individuals tend to experience negative emotions when they realize they have violated egalitarian standards, and those who are especially committed to them feel strong self-directed emotions, such as guilt and compunction (Monteith, Arthur, \& Flynn, 2010).

Kovel (1970) was among the first to describe the phenomenon of "aversive racism", whereby individuals may endorse principles of racial equality, sympathize with victims of past injustices, and genuinely regard themselves as nonprejudiced. At the same time, however, aversive racists possess conflicting, often nonconscious, negative attitudes about members of other groups that are rooted in basic psychological processes, such as social categorization, that promote racial bias (Dovidio \& Gaertner, 2004; Gaertner \& Dovidio, 1986; Pearson, Dovidio, \& Gaertner, 2009). Aversive racism can be observed wherever there is a strong tradition of egalitarianism, such as in the USA (Gaertner \& Dovidio, 1986), Canada (Son Hing, Chung-Yan, Hamilton, \& Zanna, 2008), and most European democratic societies (e.g., Hodson, Hooper, Dovidio, \& Gaertner, 2005; Kleinpenning \& Hagendoorn, 1993; Monteiro, França, \& Rodrigues, 2009).
The aversive racism framework helps to identify when discrimination against Black people and other minority groups is likely to occur. Because aversive racists recognize and accept egalitarian values and truly aspire to be non-prejudiced, they should not exhibit bias in situations in which discrimination would be apparent to others and-just as importantly-to themselves. At the same time, aversive racists' unconscious negativity is likely to surface in subtle, indirect, and rationalizable ways. Discrimination, in other words, is likely to occur when social norms against prejudice or inequality are weak or relaxed, when guidelines for appropriate behavior are vague or unspecified, or when the basis for social judgment is ambiguous. Importantly, given the theme of this special issue, discrimination will result when an aversive racist can justify a negative response on the basis of some factor other than race. Under these circumstances, aversive racists may engage in behaviors that ultimately harm minorities but in ways that allow them to maintain self-images that are non-prejudiced and that insulate them from recognizing their behavior as illegitimate. Support for the aversive racism framework has been obtained across a broad range of experimental contexts, including interpersonal judgments, helping behavior both inside and outside of the laboratory, selection decisions in employment and college admissions, and policy and legal decisions (Dovidio \& Gaertner, 2004; Pearson et al., 2009).

Sears (1988) observed that "symbolic racism"—-understood as a blend of negative racial affect picked up in childhood with individualistic, politically conservative opinions and valuespermits opposition to a range of policies that are designed to promote the general welfare and advancement of members of disadvantaged groups (Henry \& Sears, 2002; Sears \& Henry, 2005). This is because symbolic racism enables adherents to deny that bias still exists (e.g., "racism is a thing of the past"), justifies the disadvantaged status of others through victimblaming attributions (e.g., "they are lazy"), or legitimizes opposition to the policy as a way of upholding principles of fairness (e.g., "they have made excessive demands" or "they have gotten more than they deserve").

Crandall and Eshleman (2003), building on socialnormative assumptions that are similar to those underpinning the study of aversive racism, proposed the justificationsuppression model, which holds that individuals may have internalized egalitarian values, but may hold prejudiced beliefs anyway. Prejudice is usually suppressed by antiprejudice norms and personal standards, but the bias will be expressed whenever a justification that allows the individual to express prejudice without being sanctioned is available. Presumably, ideologies that legitimize the existing social order would be prime candidates to "release" prejudicial responses (e.g., Jost \& Banaji, 1994; Sidanius \& Pratto, 1999). Similarly, according to the justified discrimination model, legitimation is a mediating mechanism by which prejudice leads to discrimination in ostensibly egalitarian contexts (Pereira, Vala, \& Costa-Lopes, 2010). When Portuguese participants were made to think about Turkish people as being less than fully human, they perceived them as more likely to pose a symbolic threat to European society, and they were more likely to oppose their entrance into the European Unionbut only when an egalitarian norm was also activated (Pereira, Vala, \& Leyens, 2009). 


\section{Social Dominance Theory and Maintenance of Group Hierarchies}

According to Social Dominance Theory (Sidanius, Pratto, \& Mitchell, 1994), human societies tend to organize themselves as group-based social hierarchies where at least one group enjoys greater social status and power than other groups. Sidanius and Pratto (1999; see also Lee, Pratto, \& Johnson, 2011; Sidanius, Pratto, van Laar, \& Levin, 2004) evoke both individual and institutional factors to explain how group hierarchies are formed and maintained. According to the theory, these group hierarchies are maintained through legitimizing myths, that is, consensually shared social ideologies that justify the behavior that distributes the positive and negative social value within the social system. The theory distinguishes between two functional types of legitimizing myths: "hierarchy-enhancing" legitimizing myths and "hierarchy-attenuating" legitimizing myths. The first kind provides the moral and intellectual justifications for group-based oppression and social inequality. People endorse these ideologies that legitimize inequality as a function of their general desire for group-based dominance. This general desire has been termed social dominance orientation (SDO).

The typical example of a hierarchy-enhancing legitimizing myth identified within this theory is meritocratic ideology. This belief system locates the cause of status differences in the individual talents and efforts of group members. Although meritocracy states that people should be judged on the basis of their abilities, not their group membership, people often infer the quality of a person's input on the basis of the status of the groups to which they belong. Stronger endorsement of meritocracy among members of socially disadvantaged groups (e.g., women and Latina/os) is related to greater blame ascribed to their group and weaker attributions to racism or sexism for social inequality (e.g., McCoy \& Major, 2007). The effects of emphasizing meritocracy manifest themselves cross culturally. For example, emphasizing the value of meritocracy led Portuguese citizens to more strongly oppose the entry of the Turkish people (perceived as a lower-status group) to the European Union (Pereira et al., 2009). In New Zealand, stronger endorsement of meritocracy by White people, the socially dominant group, was associated with more negative attitudes toward biculturalism (Sibley \& Wilson, 2007).

\section{System Justification Theory and Maintenance of the Status Quo}

According to system justification theory, people are motivated to defend, justify, and bolster aspects of the status quo, including existing social, economic, and political systems, institutions, and arrangements (Jost \& Banaji, 1994; Jost \& Hunyady, 2005). This framework focuses on the social and psychological processes by which people-as individuals and as members of groups-legitimize the institutions and arrangements in the society, often coming to see social inequality as not only legitimate but also natural and necessary. As Jost and van der Toorn (2012) noted,

System justification motivation is theorized to manifest itself in a number of different ways (e.g., in terms of stereotyping, ideology, attribution), to occur implicitly (i.e., nonconsciously) as well as explicitly, and to serve underlying epistemic, existential, and relational needs (p. 313).

Consistent with the proposition that people have fundamental system-justifying goals, threats to the social system motivate individuals to defend it (Jost et al., 2010). For example, Kay, Jost, and Young (2005) found that US participants exposed to a passage that included system-threatening statements (e.g., "These days, many people in the U.S. feel disappointed with the nation's condition") actively attempted to bolster the sagging legitimacy of the system by judging powerful people to be more intelligent and independent, and powerless people to be the opposite. These effects occur cross culturally. When Israeli citizens read a similar system-threat passage about Israel, they relied more heavily on stereotypes to rationalize social and economic inequalities between Ashkenazi and Mizrahi Jews (Jost, Kivetz, Rubini, Guermandi, \& Mosso, 2005).

Recent work on system justification theory has focused on factors that influence the need to engage in system justification and thus ultimately on the legitimation of social inequality. For example, people are especially likely to justify and rationalize the way things are when they feel dependent upon the overarching social, economic, or political system. In a series of studies conducted in educational, political, and legal settings, van der Toorn, Tyler, and Jost (2011) found that the more individuals experienced outcome dependence with respect to a given authority figure, the more legitimacy they ascribed to him or her, and the more deference they reported after adjusting for procedural treatment (see also van der Toorn et al., in press).

Another closely related situational variable that activates system justification tendencies is system inevitability-the extent to which a system is experienced as inescapable or unavoidable. That is, when individuals feel trapped in a particular social system, they are more likely to defend and justify its policies and practices. For instance, Laurin, Shepherd, and Kay (2010) found that when participants were led to believe that their freedom of movement was highly restricted-when leaving their country was extremely difficult - they expressed stronger system justification tendencies even in domains that were unrelated to emigration policy, such as gender disparities in society. Conversely, when the status quo is regarded as clearly changeable, individuals are less motivated to defend it (Johnson \& Fujita, 2012).

A distinctive tenet of system justification theory is that individuals, even those who are disadvantaged by the status quo, possess at least some degree of system justification motivation (Jost \& van der Toorn, 2012). This system-justifying motivation is often activated unconsciously, without deliberate awareness or intent (Jost, Pelham, \& Carvallo, 2002; Jost et al., 2004; Rudman, Feinberg, \& Fairchild, 2002). As a consequence, people engage in biased information processing in favor of system-serving conclusions (e.g., Hennes, Jost, \& Ruisch, 2013) and exhibit "classic" properties of goal pursuit, so that people may engage in multiple, functionally interchangeable means of reaching the desired end state of justifying the system (Jost et al., 2010; Kay et al., 2005). The social systems that individuals are motivated to justify may be small in size and scope, such as (at the most micro level of analysis) relationship dyads and family units, or they may extend to formal and informal status hierarchies, institutions and organizations, 
or (at the most macro level of analysis) even entire nations or societies (Fiske, 2010; Wakslak, Jost, \& Bauer, 2011).

Understanding the dynamics of these basic systemjustifying needs provides important insights about why people endorse ideologies that promote the maintenance of the status quo even when this endorsement legitimizes social inequality. In particular, system-justifying ideologies are sets of beliefs that "can explain or make sense of a social system in ways that provide a rationale for the appropriateness or reasonableness of differences in authority, power, status, or wealth" (Tyler, 2006, p. 376). Jost and Hunyady (2005) have identified a number of common system-justifying ideologies, including the Protestant work ethic, meritocratic assumptions, fair market ideology, belief in a just world, benevolent sexism, power distance, SDO, authoritarianism, and political conservatism.

System-justifying ideologies also undermine support for the redistribution of resources and inhibit the kinds of emotional responses (e.g., moral outrage, guilt, and frustration) that stimulate efforts to help the disadvantaged (Wakslak, Jost, Tyler, \& Chen, 2007). Thus, system-justifying ideologies are potentially powerful tools for legitimating inequality, perpetuating social disparities, and maintaining support for the status quo. In summary, the goal to defend, bolster, and justify the social system leads individuals and groups to exaggerate the system's virtues, downplay its vices, and see the societal status quo as more fair and desirable than it actually is. This motive contributes to an inherently conservative tendency to vindicate the status quo (Jost, Glaser, Kruglanski, \& Sulloway, 2003).

In the next section, we briefly review the articles in this special issue, which address legitimation of social inequality from individual-level, group-level, and societal-level, or system-level perspectives. The articles, which are diverse in their perspectives and methodologies, collectively enhance our understanding of legitimation, both extending existing theories and integrating perspectives across different levels of analysis.

\section{OVERVIEW OF ARTICLES IN THE SPECIAL ISSUE}

The goal of this special issue of the European Journal of Social Psychology is to bring together cutting-edge research that addresses social and psychological processes of legitimation when it comes to social and economic inequalities, focusing on the origins, manifestations, and consequences of legitimation. In some ways, this is the first attempt to take stock of recent work in this area since literature reviews were published by Jost and Major (2001) and Tyler (2006). In terms of scope, we sought to include articles that consider the perspectives of members of disadvantaged as well as advantaged groups and to integrate interdisciplinary and multimethodological approaches, including laboratory research as well as cross-sectional and longitudinal surveys.

From over 50 initial submissions, we selected nine empirical articles for inclusion in this special issue. The first two articles focus on societal or system-level variables that are quite similar (or at least compatible), namely perceived system longevity and perceived system stability; in both cases, the researchers investigate the impact of these variables on the legitimation of inequality. Both articles adopt a system justification perspective, focusing on cognitive-motivational tendencies to justify aspects of the societal status quo.

The first article, by Blanchar and Eidelman, features two ingenious experiments that contribute to our understanding of ideological responses to social and economic inequalities by systematically manipulating the perceived longevity of the system. In their first study, the researchers represent the intellectual origins of capitalism - as exemplified by Adam Smith's Wealth of Nations - as relatively recent or old with the use of a subjective timeline. They observe that the economic system in the USA is perceived by American, British, and Canadian participants as more legitimate-and inequality under capitalism as more justifiable-when the origins of capitalism are presented as significantly older. In a second study, Blanchar and Eidelman find that depicting the Indian Caste system as especially old causes both Indian and American participants to justify inequality under the Caste system more strongly. In both studies, the effects are mediated by economic system justification.

Laurin, Gaucher, and Kay illuminate a similar phenomenon in the second article of this special issue by demonstrating that the perceived stability of certain features of the social system influences the justification of the system as a whole. In Study 1, participants who witnessed stability (rather than change) in the domain of gender inequality in business expressed less willingness to support initiatives targeting inequalities in unrelated domains. In Study 2, the mere activation of the abstract concept of stability increased the spontaneous tendency to justify inequalities present within social systems (although this effect only emerged for politically liberal participants).

The third article, by Jasko and Kossowska, also addresses perceptions of legitimacy at the system level, but it considers group-level dynamics as well. Specifically, this article focuses on the implications of superordinate group identification. It demonstrates that the attempt to create harmony by emphasizing a common ingroup identity results, perhaps ironically, in a greater acceptance of inequality in society (Dixon, Levine, Reicher, \& Durrheim, 2012; Saguy, Tausch, Dovidio, \& Pratto, 2009). This "darker side of $w e$ " is described in two studies that analyze the role of superordinate identification on the legitimation of intergroup inequalities in Poland. In Study 1, the researchers find that when the participants' group is disadvantaged, making the superordinate identity salient (i.e., Polish national identification) led to a stronger justification of the unequal financial system. In fact, this legitimation effect was stronger among members of the minority (low-status) than majority (high-status) groups. In Study 2, the authors extend this effect to intergroup relations on the basis of religion, demonstrating that national identification is related to a stronger degree of justification of the display of crucifixes in public schools among nonbelievers. Taken together, the two studies by Jasko and Kossowska suggest how strategies that are designed to create social harmony (e.g., emphasis on commonality or assimilation) also solidify the societal status quo by increasing the minority group members' support for the values and priorities of the majority group.

The next four articles focus on problems of prejudice. França and Monteiro address one of the basic motivations 
underlying legitimation: the need to preserve a positive selfimage by complying with social norms. Moreover, the authors employ a socio-developmental approach to the issue and invoke processes of justification to delineate the circumstances under which individuals exhibit discriminatory behavior. In Study 1, the researchers demonstrate that older White children in Brazil exhibit more discriminatory behavior only when an ostensibly non-racial reason (i.e., the fact that White children worked harder than the other children) can be used to "justify" treating Black children less favorably than White children. In Study 2, they demonstrate that older children only discriminate against Black children when the normative structure of the situation is ambiguous, whereas younger children discriminate regardless of the presence or absence of an anti-prejudice norm.

The fifth and sixth articles combine the study of prejudice and discrimination with a focus on legitimation processes associated with the maintenance of social hierarchies, such as those associated with authoritarianism and SDO (Altemeyer, 1998; Sidanius \& Pratto, 1999). In the fifth article, Carvacho, Zick, Haye, González, Manzi, Kocik, and Bertl address a question that has persisted for decades in the social sciences: What is the nature of the relationship between social class and prejudice? Using representative samples of survey respondents from several European countries, Carvacho et al. find that lower levels of income and education (two standard indicators of social class) are associated with higher levels of prejudice and that these relationships are mediated by right-wing authoritarianism (RWA) and SDO. Drawing on longitudinal data obtained in Chile and Germany, they find that RWA is a more consistent mediator of the relationship between social class and prejudice than is SDO, especially when it comes to the effects of education.

Bahns and Crandall demonstrate that beliefs about the acceptability of social inequality — as measured in terms of SDO — may be used to legitimize antigay discrimination when relative status positions between gay and straight groups are perceived to be shifting. In an experimental study that included behavioral measures, the authors show that heterosexuals who believed that social inequality is legitimate (high-SDO) reacted defensively to a perceived status gain by gays - by donating money to antigay causes. However, when perceived threat to group position was low, high-SDO heterosexuals actually exhibited enhanced tolerance by increasing their donations to the pro-gay cause. These results suggest that endorsing social inequality legitimates prejudice and discrimination but only affects behavior when status positions are threatened.

The seventh article, which is by Saguy, Chernyak-Hai, Andrighetto, and Bryson, also investigates, albeit indirectly, the role of threat. These authors focus on the concept of feeling wronged, which refers to "advantaged group members who experience themselves being unfairly accused of harboring racial or ethnic biases" (Saguy et al., p. 292, this issue). On the basis of the idea that members of advantaged groups see those accusations as a threat to their ingroup image, Saguy and colleagues hypothesized that participants who "feel wronged" would need to restore their morally impaired identity. In this attempt to restore their image, advantaged group members frame social inequality that benefits their group as legitimate and justified. In the first study, the extent to which advantaged group members feel wronged predicts their perceptions of intergroup inequality as more legitimate, which discourages them from promoting social change. In the second study, the authors manipulated a sense of feeling wronged by emphasizing unfair blame directed toward the advantaged ingroup. In this study, using a sample of Israeli-Jews and focusing on Jewish-Arab relations in Israel, the sense of feeling wronged undermined participants' willingness to participate in actions redressing inequality, through legitimacy perceptions.

The last two articles focus on gender inequality and bring us back full circle to a system justification perspective. Brown and Diekman analyze whether individuals' system justification motivation serves to undermine social change. Specifically, they propose that the presence of even a single exemplar of an underrepresented group (e.g., a female political candidate) in an unequally distributed political system (e.g., a parliament composed by a strong majority of male members) would increase the motivation to legitimize that unequal system. Accordingly, in the first two experiments, the authors demonstrate that merely mentioning the presence of female political candidates leads both men and women to score higher on general system justification-as measured with Kay and Jost's (2003) scale. In Experiment 3, they find that the presence of female political candidates increases individuals' implicit preferences associated with maintaining the current sociopolitical system.

The final article included in the special issue, which is coauthored by McCoy, Wellman, Cosley, Saslow, and Epel, hightlights one reason why low-status group members might endorse certain system-justifying ideologies that legitimize their own state of disadvantage. The authors propose that low-status group members, just like high-status group members, benefit psychologically from the endorsement of meritocratic beliefs insofar as such beliefs strengthen perceptions of control over future outcomes. In two studies, the authors observe a positive relationship between the belief in meritocracy and well-being (self-esteem and physical health), which is mediated by perceived control. This pattern holds for relatively high-status and low-status individuals (with status operationalized in terms of gender and socioeconomic status). This last article may help to explain why those who are not privileged by the status quo may nevertheless want to see it as fair, legitimate, and just.

\section{CONCLUDING REMARKS}

Processes of legitimation may take a variety of forms, embody different motivations, and produce a wide range of social consequences. This heterogeneity is reflected in the number and diversity of theoretical models, focusing on different levels of analysis that have been brought to bear on these issues (Jost \& Major, 2001). As suggested by Jost, Burgess, and Mosso (2001), these processes operate at the level of the individual, the group, and the system. We identified three basic goals or motives served by processes of legitimation: (i) the selfserving goal to preserve a positive image by, among other things, complying with socially desirable norms and values; (ii) the group-serving goal to promote social dominance and hegemonic, hierarchical arrangements; and (iii) the system- 
serving goal to defend, bolster, and justify the societal status quo. These various approaches to understanding legitimation and social inequality emphasize distinct antecedents and consequences, as well as different functions served by legitimation. At the same time, these different approaches are perhaps more compatible than is often realized, and (taken in conjunction) they would appear to constitute the most common social psychological motivations for the legitimation of inequality.

Legitimation is a powerful influence in the maintenance of social inequality because it helps to resolve potential conflicts derived from the tension between the individual's desire to adhere to egalitarian values and standards and, at the same time, to act in a manner that is consistent with their devaluation of socially disadvantaged groups and commitment to the existing social order (e.g., Jost, Wakslak, \& Tyler, 2008; Pereira et al., 2010). Moreover, the effects of legitimation in reinforcing social inequality are often subtle, especially insofar as they are accompanied by public compliance with social norms and buttressed by hierarchy-enhancing myths and system-justifying ideologies - some of which seem to be endorsed by members of disadvantaged as well as advantaged groups. Although processes of legitimation may operate subtly, their consequences are profound; such processes may obscure the true nature of existing inequalities and propel them into the future through a matrix of excuses and justifications. Whether processes of legitimation operate consciously or unconsciously or exert their influence on members of dominant or non-dominant groups (or both), they systematically perpetuate and often increase the degree of inequality in the society.

Although the articles collected in this special issue significantly advance the study of the legitimation of social inequality in many ways, important conceptual and empirical questions remain. For instance, these articles make a clear and convergent case that legitimation operates systematically at the individual, group, and system levels to support social inequality; the work also identifies individual differences and social and contextual factors that moderate legitimation. However, future work might consider more fully the role of intrapersonal processes-psychological mechanisms within individuals - that determine the ways in which individuals legitimate social inequality. It is important to bear in mind that such processes are not necessarily consciously undertaken or strategic in a deliberate sense. According to the aversive racism framework, the negative feelings that motivate discrimination are often automatic and unconscious (Dovidio \& Gaertner, 2004). Similarly, many of the processes in system justification involve the automatic internalization of attitudes that support the status quo rather than an effortful search for theories and explanations that can be used explicitly to justify the promotion of inequality. Indeed, paternalism (Jackman, 1994), benevolent sexism (Glick \& Fiske, 2001), and dependency-oriented helping (Nadler \& Halabi, 2006) are all ostensibly prosocial activities that reinforce the superior status of one's own group over another, and each can be pursued either consciously or unconsciously (Bargh \& Huang, 2009; Gollwitzer \& Bargh, 2005). At the same time, there are certainly circumstances in which legitimation may be carried out through deliberative and manipulative means (as in the case of propagandistic activity). Future research might therefore investigate the circumstances in which legitimation may be undertaken consciously or unconsciously and the consequences of different legitimation processes for perpetuators of bias as well as their targets.

In addition, we believe that research on the legitimation of social inequality represents an important model for expanding the theoretical and empirical perspectives of social psychology more generally. Much of social psychology today focuses on intraindividual processes and individual-level behavior. Work on legitimation, by contrast, incorporates group-level and system-level processes as well. Understanding legitimation as a social and cultural phenomenon thus provides an important bridge to allied disciplines, such as sociology and political science, while maintaining psychology's traditional focus on individual-level processes. Research on the legitimation of inequality may therefore stimulate renewed attention to multiple levels of analysis-individual, group, and societal levels (Doise, 1986; Stangor \& Jost, 1997)—and, even more importantly, to the dynamic interrelationships among processes operating at these different levels.

In conclusion, with the publication of this special issue, we have sought to increase our understanding of the relationship between legitimation and inequality by highlighting general theoretical themes and showcasing new empirical studies that advance research on this topic in novel and important ways. Collectively, the articles demonstrate the vitality of current work on this topic. They also demonstrate the promise of future research not only for developing a deeper and more integrative theoretical understanding of the issue but also for devising interventions that have the potential to replace broad ideological assumptions about fairness with specific values, belief systems, and personal commitments that facilitate the attainment of social equality in practice.

\section{ACKNOWLEDGEMENTS}

The preparation of this paper and editing of this Special Issue were supported by a grant from the Fundação para a Ciência e a Tecnologia (FCT, Portugal) awarded to Cicero Roberto Pereira and Rui Costa-Lopes (PTDC/PSI-PSO/114159/2009), and a NIH Grant RO1HL 0856331-0182 and a NIDA Grant 1R01DA029888-01 awarded to John F. Dovidio. The guest editors would like to thank Tom Postmes for comments on an earlier version of this article and to the entire team at the European Journal of Social Psychology for their support throughout the process.

\section{REFERENCES}

Altemeyer, B. (1998). The 'other authoritarian personality'. In M. P. Zanna (Ed.), Advances in experimental social psychology (Vol. 30, pp. 47-92). San Diego, CA: Academic Press.

Bargh, J. A., \& Huang, J. Y. (2009). The selfish goal. In G. B. Moskowitz, \& H. Grant (Eds.), The psychology of goals (pp. 127-152). New York: Guilford. Berger, P. L., \& Luckmann, T. (1966). The social construction of reality: A treatise in the sociology of knowledge. Garden City, NY: Anchor Books.

Blumer, H. (1958). Race prejudice as a sense of group position. The Pacific Sociological Review, 1, 3-7.

Boehm, C. (2012). Moral origins: The evolution of virtue, altruism, and shame. New York: Basic Books. 
Brosnan, S. F. (2006). Nonhuman species' reactions to inequity and their implications for fairness. Social Justice Research, 19, 153-185.

Corning, P. (2011). The fair society: The science of human nature and the pursuit of social justice. Chicago: University of Chicago Press.

Crandall, C. S., \& Eshleman, A. (2003). A justification-suppression model of the expression and experience of prejudice. Psychological Bulletin, 129, 414-446.

Darley, J. M. (1992). Social organization for the production of evil. Psychological Inquiry, 3, 199-218.

Deutsch, M. (1985). Distributive justice. New Haven, CT: Yale University Press.

Dixon, J., Levine, M., Reicher, S., \& Durrheim, K. (2012). Beyond prejudice: Are negative evaluations the problem and is getting us to like one another more the solution? Behavioral and Brain Sciences, 35, 411-425.

Doise, W. (1986). Levels of explanation in social psychology. Cambridge, UK: Cambridge University Press.

Dovidio, J. F., \& Gaertner, S. L. (2004). Aversive racism. In M. P. Zanna (Ed.), Advances in experimental social psychology (Vol. 36, pp. 1-51). San Diego, CA: Academic Press.

Dovidio, J. F., Hewstone, M., Glick, P., \& Esses, V. M. (2010). Prejudice, stereotyping, and discrimination: Theoretical and empirical overview. In J. F. Dovidio, M. Hewstone, P. Glick, \& V. M. Esses (Eds.), SAGE handbook of prejudice, stereotyping, and discrimination (pp. 3-28). London: Sage.

Ellemers, N. (2001). Individual upward mobility and the perceived legitimacy of intergroup relations. In J. T. Jost, \& B. Major (Eds.), The psychology of legitimacy: Emerging perspectives on ideology, justice, and intergroup relations (pp. 205-222). New York: Cambridge University Press.

Faust, D. G. (Ed.). (1981). The ideology of slavery: Proslavery thought in the antebellum south, 1830-1860. Baton Rouge, LA: Louisiana State University Press.

Fields, B. (1990). Slavery, race, and ideology in the United States of America. New Left Review, 181, 95-118.

Fiske, S. T. (2010). Interpersonal stratification: Status, power, and subordination. In S. T. Fiske, D. T. Gilbert, \& G. Lindzey (Eds.), Handbook of social psychology (5th ed., Vol. 2, pp. 941-982). Hoboken, NJ: Wiley.

Gaertner, S. L., \& Dovidio, J. F. (1986). The aversive form of racism. In J. F. Dovidio, \& S. L. Gaertner (Eds.), Prejudice, discrimination, and racism (pp. 61-89). Orlando, FL: Academic Press.

Glick, P., \& Fiske, S. T. (2001). Ambivalent sexism. In M. P. Zanna (Ed.), Advances in experimental social psychology (Vol. 33, pp. 115-188). Thousand Oaks, CA: Academic Press.

Gollwitzer, P. M., \& Bargh, J. A. (2005). Automaticity in goal pursuit. In A. Elliot, \& C. Dweck (Eds.), Handbook of competence and motivation (pp. 624-646). New York: Guilford.

Hafer, C. L., \& Bègue, L. (2005). Experimental research on just-world theory: Problems, developments, and future challenges. Psychological Bulletin, $131,128-167$.

Hennes, E. P., Jost, J. T., \& Ruisch, B. (2013). Economic concerns bias evaluation and recall of climate change information. Manuscript submitted for publication.

Henry, P. J., \& Sears, D. O. (2002). The Symbolic Racism 2000 Scale. Political Psychology, 23, 253-283.

Hochschild, J. (1981). What's fair? American beliefs about distributive justice. Cambridge, MA: Harvard University Press.

Hodson, G., Hooper, H., Dovidio, J. F., \& Gaertner, S. L. (2005). Aversive racism in Britain: Legal decisions and the use of inadmissible evidence. European Journal of Social Psychology, 35, 437-448.

Jackman, M. R. (1994). The velvet glove: Paternalism and conflict in gender, class, and race relations. Berkeley, CA: University of California Press.

Johnson, C. J., Dowd, T. J., \& Ridgeway, C. L. (2006). Legitimacy as a social process. Annual Review of Sociology, 32, 53-78.

Johnson, I. R., \& Fujita, K. (2012). Change we can believe in: Using perceptions of changeability to promote system-change motives over system-justification motives in information search. Psychological Science, 23, 133-140.

Jost, J. T., \& Banaji, M. R. (1994). The role of stereotyping in systemjustification and the production of false consciousness. British Journal of Social Psychology, 33, 1-27.

Jost, J. T., Banaji, M. R., \& Nosek, B. A. (2004). A decade of system justification theory: Accumulated evidence of conscious and unconscious bolstering of the status quo. Political Psychology, 25, 881-920.

Jost, J. T., Burgess, D., \& Mosso, C. O. (2001). Conflicts of legitimation among self, group, and system: The integrative potential of system justification theory. In J. T. Jost, \& B. Major (Eds.), The psychology of legitimacy: Emerging perspective on ideology, justice, and intergroup relations (pp. 363-388). Cambridge: Cambridge University Press.

Jost, J. T., Glaser, J., Kruglanski, A. W., \& Sulloway, F. J. (2003). Political conservatism as motivated social cognition. Psychological Bulletin, 129, 339-375.

Jost, J. T., \& Hunyady, O. (2005). Antecedents and consequences of systemjustifying ideologies. Current Directions in Psychological Science, 14, 260-265.
Jost, J. T., \& Kay, A. C. (2010). Social justice: History, theory, and research. In S. T. Fiske, D. T. Gilbert, \& G. Lindzey (Eds.), Handbook of social psychology (5th ed., Vol. 2, pp. 1122-1165). Hoboken, NJ: Wiley.

Jost, J. T., Kivetz, Y., Rubini, M., Guermandi, G., \& Mosso, C. (2005). System-justifying functions of complementary regional and ethnic stereotypes: Cross-national evidence. Social Justice Research, 18, 305-333.

Jost, J. T., Liviatan, I., van der Toorn, J., Ledgerwood, A., Mandisodza, A., \& Nosek, B. A. (2010). System justification: How do we know it's motivated? In R. C. Bobocel, A. C. Kay, M. Zanna, \& J. Olson (Eds.), The psychology of justice and legitimacy: The Ontario symposium (Vol. 11, pp. 173-203). Hillsdale, NJ: Erlbaum.

Jost, J.T., \& Major, B. (2001). Emerging perspectives on the psychology of legitimacy. In J. T. Jost, \& B. Major (Eds.), The psychology of legitimacy: Emerging perspectives on ideology, justice, and intergroup relations (pp. 3-30). New York: Cambridge University Press.

Jost, J. T., Pelham, B. W., \& Carvallo, M. R. (2002). Non-conscious forms of system justification: Implicit and behavioral preferences for higher status groups. Journal of Experimental Social Psychology, 38, 586-602.

Jost, J. T., \& van der Toorn, J. (2012). System justification theory. In P. A. M. van Lange, A. W. Kruglanski, \& E. T. Higgins (Eds.), Handbook of theories of social psychology (Vol. 2, pp. 313-343). London: Sage.

Jost, J. T., Wakslak, C., \& Tyler, T. R. (2008). System justification theory and the alleviation of emotional distress: Palliative effects of ideology in an arbitrary social hierarchy and in society. In K. Hegtvedt, \& J. Clay-Warner (Eds.), Justice: Advances in group processes (Vol. 25, pp. 181-211). Bingley: JAI/Emerald.

Kay, A. C., \& Jost, J. T. (2003). Complementary justice: Effects of "poor but happy" and "poor but honest" stereotype exemplars on system justification and implicit activation of the justice motive. Journal of Personality and Social Psychology, 85, 823-837.

Kay, A. C., Jost, J. T., \& Young, S. (2005). Victim derogation and victim enhancement as alternate routes to system justification. Psychological Science, 16, 240-246.

Kelman, H. C. (2001). Reflections on the social and psychological processes of legitimization and delegitimization. In J. T. Jost, \& B. Major (Eds.), The psychology of legitimacy: Emerging perspectives on ideology, justice, and intergroup relations (pp. 54-73). Cambridge: Cambridge University Press.

Kleinpenning, G., \& Hagendoorn, L. (1993). Forms of racism and the cumulative dimension. Social Psychology Quarterly, 56, 21-36.

Kluegel, J. R., \& Smith, E. R. (1986). Beliefs about inequality: Americans' view of what is and what ought to be. Hawthorne, NJ: Aldine de Gruyer.

Kovel, J. (1970). White racism: A psychohistory. New York: Pantheon.

Laurin, K., Shepherd, S., \& Kay, A. C. (2010). Restricted emigration, system inescapability, and defense of the status quo: System-justifying consequences of restricted exit opportunities. Psychological Science, 21, 1075-1082.

Lee, I. C., Pratto, F., \& Johnson, B. T. (2011). Intergroup consensus/disagreement in support of group-based hierarchy: An examination of socio-structural and psycho-cultural factors. Psychological Bulletin, 137, 1029-1064.

Lerner, M. J. (1980). The belief in a just world: A fundamental delusion (pp. 11-12). New York: Plenum Press.

Lerner, M. J., \& Clayton, S. (2011). Justice and self-interest. New York: Cambridge University Press.

Luhmann, N. (1969). Legitimation durch Verfahren [legitimacy through procedural]. Berlin: Luchterhand.

Luo, L., \& Hsieh, Y.-H. (1997). Demographic variables, control, stress, support and health among the elderly. Journal of Health Psychology, 2, 97-106.

Major, B. (1994). From social inequality to personal entitlement: The role of social comparisons, legitimacy appraisals, and group membership. In M. P. Zanna (Ed.), Advances in experimental social psychology (Vol. 26, pp. 293-355). San Diego, CA: Academic Press.

McCoy, S. K., \& Major, B. (2007). Priming meritocracy and the psychological justification of inequality. Journal of Experimental Social Psychology, 43, 341-351.

Milgram, S. (1974). Obedience to authority. New York. Harper Colophon Books. Monteiro, M. B., França, D. X., \& Rodrigues, R. (2009). The development of intergroup bias in childhood: How social norms can shape children's racial behaviours. International Journal of Psychology, 44, 29-39.

Monteith, M. J., Arthur, S. A., \& Flynn, S. M. (2010). Self-regulation and bias. In J. F. Dovidio, M. Hewstone, P. Glick, \& V. M. Esses (Eds.), SAGE handbook of prejudice, stereotyping, and discrimination (pp. 493-507). London: Sage.

Moscovici, S. (1988). Notes towards a description of social representations. European Journal of Social Psychology, 18, 211-250.

Nadler, A., \& Halabi, S. (2006). Intergroup helping as status relations: Effects of status stability, identification, and type of help on receptivity to highstatus group's help. Journal of Personality and Social Psychology, 91, 97-110.

O'Brien, L. T., \& Major, B. (2005). System justifying beliefs and psychological well-being: The roles of group status and identity. Personality and Social Psychology Bulletin, 31, 1718-1729. 
Opotow, S. (1990). Moral exclusion and injustice. Journal of Social Issues, 46, 1-20. Pearson, A. R., Dovidio, J. F., \& Gaertner, S. L. (2009). The nature of contemporary prejudice: Insights from aversive racism. Social and Personality Psychology Compass, 3, 314-338.

Pereira, C. R., Vala, J., \& Costa-Lopes, R. (2010). From prejudice to discrimination: The legitimizing role of perceived threat in discrimination against immigrants. European Journal of Social Psychology, 40, 1231-1250.

Pereira, C. R., Vala, J., \& Leyens, J. (2009). From infra-humanization to discrimination: The mediation of symbolic threat needs egalitarian norms. Journal of Experimental Social Psychology, 45, 336-344.

Raven, B., \& French, J. R. P. (1958). Legitimate power, coercive power, and observability in social influence. Sociometry, 21, 83-97.

Rokeach, M. (1973). The nature of human values. New York: Wiley.

Rudman, L. A., Feinberg, J., \& Fairchild, K. (2002). Minority members' implicit attitudes: Automatic ingroup bias as a function of group status. Social Cognition, 20, 294-320.

Saguy, T., Tausch, N., Dovidio, J. F., \& Pratto, F. (2009). The irony of harmony: Intergroup contact can produce false expectations for equality. Psychological Science, 20, 114-121.

Schuman, H., Steeh, C., Bobo, L., \& Krysan, M. (1997). Racial attitudes in America: Trends and interpretations. Cambridge, MA: Harvard University Press.

Schwartz, S. H. (1992). Universals in the content and structure of values: Theoretical advanced and empirical tests in 20 countries. In M. P. Zanna (Ed.) Advances in experimental social psychology (Vol. 25, pp. 1-65). San Diego, CA: Academic Press.

Sears, D. O. (1988). Symbolic racism. In P. A. Katz, \& D. A. Taylor (Eds.), Eliminating racism: Profiles in controversy (pp. 53-84). New York: Plenum Press.

Sears, D. O., \& Henry, P. J. (2005). Over thirty years later: A contemporary look at symbolic racism. In M. P. Zanna (Ed.), Advances in experimental social psychology (vol. 37, pp. 95-150). San Diego, CA: Academic Press.

Sibley, C. G., \& Wilson, M. S. (2007). Political attitudes and the ideology of equality: Differentiating support for liberal and conservative political parties in New Zealand. New Zealand Journal of Psychology, 36, 72-84.

Sidanius, J. (1993). The psychology of group conflict and the dynamics of oppression: A social dominance perspective. In W. McGuire, \& S. Iyengar (Eds.), Current approaches to political psychology (pp. 183-219). Durham, NC: Duke University Press.

Sidanius, J., \& Pratto, F. (1999). Social dominance: An inter-group theory of social hierarchy and oppression. New York: Cambridge University Press.

Sidanius, J., Pratto, F., \& Mitchell, M. (1994). In-group identification, social dominance orientation, and differential intergroup social allocation. Journal of Social Psychology, 134, 151-167.

Sidanius, J., Pratto, F., van Laar, C., \& Levin, S. (2004). Social dominance theory: Its agenda and method. Political Psychology, 25, 845-880.

Somit, A., \& Peterson, S. A. (Eds.). (1996). Research in biopolitics. Bingley: Emerald.
Son Hing, L. S., Chung-Yan, G., Hamilton, L., \& Zanna, M. (2008). A twodimensional model that employs explicit and implicit attitudes to characterize prejudice. Journal of Personality and Social Psychology, 94, 971-987.

Stangor, C., \& Jost, J.T. (1997). Individual, group, and system levels of analysis and their relevance for stereotyping and intergroup relations. In $\mathrm{R}$. Spears, P. Oakes, N. Ellemers, \& S. A. Haslam (Eds.), The social psychology of stereotyping and group life (pp. 336-358). Oxford: Blackwell.

Tajfel, H. (1981). Human groups and social categories: Studies in social psychology. New York: Cambridge University Press.

Tajfel, H., \& Turner, J. C. (1979). An integrative theory of intergroup conflict In W. G. Austin, \& S. Worchel (Eds.), The social psychology of intergroup relations (pp. 33-47). Monterey, CA: Brooks/Cole.

Taylor, S. E., \& Brown, J. D. (1988). Illusion and well-being: A socialpsychological perspective on mental health. Psychological Bulletin, 103, 193-210.

Tyler, T. R. (1989). The psychology of procedural justice: A test of the group value model. Journal of Personality and Social Psychology, 57, 830-838.

Tyler, T. R. (1997). The psychology of legitimacy: A relational perspective on voluntary deference to authorities. Personality and Social Psychology Review, 1, 323-345.

Tyler, T. R. (2006). Why people obey the law. Princeton, NJ: Princeton University Press.

Tyler, T. R. (2011). Why people cooperate. Princeton, NJ: Princeton University Press.

Tyler, T. R., \& Blader, S. L. (2000). Cooperation in groups: Procedural justice, social identity, and behavioral engagement. Philadelphia, PA: Psychology Press.

Van der Toorn, J., Feinberg, M., Jost, J. T., Kay, A. C., Tyler, T. R., Willer, R., \& Wilmuth, C. (in press). A sense of powerlessness fosters system justification: Implications for the legitimation of authority, hierarchy, and government. Political Psychology.

Van der Toorn, J., Tyler, T. R., \& Jost, J. T. (2011). More than fair: Outcome dependence, system justification, and the perceived legitimacy of authority figures. Journal of Experimental Social Psychology, 47, 127-138.

Van Zomeren, M., Postmes, T., \& Spears, R. (2008). Toward an integrative social identity model of collective action: a quantitative research synthesis of three socio-psychological perspectives Psychological Bulletin, 134, 504-535.

Wakslak, C. J., Jost, J. T., \& Bauer, P. (2011). Spreading rationalization: Increased support for large-scale and small-scale social systems following system threat. Social Cognition, 29, 288-302.

Wakslak, C. J., Jost, J. T., Tyler, T. R., \& Chen, E. (2007). System justification and the alleviation of emotional distress. Psychological Science, $18,267-274$.

Zelditch, M. (2001). Theories of legitimacy. In J. T. Jost, \& B. Major (Eds.), The psychology of legitimacy: Emerging perspective on ideology, justice, and intergroup relations (pp. 33-53). New York: Cambridge University Press. 